\title{
Does Corporate Governance Moderate the Effect of Earnings Management on Tax Aggressiveness?
}

\author{
Dewi Prastiwi \\ Faculty of Economics \\ UniversitasNegeri Surabaya \\ Surabaya, Indonesia \\ dewiprastiwi@unesa.ac.id
}

\begin{abstract}
Taxes are important for a State and company. Both have a common interest in taxes. For the State tax is a source of State income, so there is an effort to maximize tax revenue. For the company, the tax is a net income deduction. Therefore, companies frequently use earnings management to control the reporting of income that affects the tax payable. Previous research suggests that there is a relationship between aggressive financial reporting and tax reporting aggressiveness. This study aims to expand the results of previous research by re-examining the effect of earnings management on tax aggressiveness with corporate governance as a moderating variable. We use Modified-Jones Model accruals to measure earnings management, Book Tax Different (BTD) to measure tax aggressiveness, and Principal Component Analysis (PCA) to identify major dimensions of corporate governance. The results show that corporate governance is quasi moderation which means Corporate Governance is able to moderate earnings management relationship and tax aggressiveness which also become independent variable
\end{abstract}

Keyword: Earnings management, tax aggressiveness, corporate governance, PCA

\section{INTRODUCTION}

The corporate performance measurement can be depicted into the financial statement, which is the primary communication device of corporate performance toward the stakeholders, including the government. Tax is significance for corporate and government since both of them hold common interests on it. For government, it plays a role as the state income source, so there is an effort to maximize the tax revenue. On the other hand, for the corporate, the tax is the revenue deduction, calculated based on the amount of the corporate profit. Thus, it is common if the earnings management is employed by the company to control the income reporting which affects to the accrued tax. The result of the effort for tax saving conducted by the corporates in Indonesia. could be reflected on Indonesia tax ratio in 2016 which is about $11 \%$ under the standard belonging to ASEAN and Organization on Economic Cooperation and Development (OECD) countries.[1]

In terms of goal setting theory, an individual do something to gain the goal, meanwhile the goal is encouraged by motivation. Beside maximizing the profit, [2] argues that one of the earnings management motivation is reducing the net profit which impacts the company tax expense. Similar to Mulyadi [3] statement, the profit management is commonly applied for minimizing the tax liability.

In their research of correlation between financial reporting and tax aggressiveness, Frank [4] denotes that both of them belong to the intense, positive relation. It possibly happens as there are differences in standard of financial accounting and of the tax law, permitting the company to utilize it by increasing the income and reducing the taxable income in the same reporting period. Yet, the dissimilar result is indicated by Heltzer [5] argument in investigating the financial trade off the manager faces for the incentive which is contrary to report the commercial income, and at the same time to report the low taxable income. The result shows that the aggressive financial reporting culture has no correlation to their tax reporting. Badertscher [6] probe the tax and non-tax factors affecting to the manager choices in managing the earning before tax. As the result, the company uses profit management as the effort for achieving the tax saving and the manager prefers to managing the income by the ways which is not taxable.

In agency theory point of view, as the agent, manager conducts the profit management to maximize the principal, and the tax management to prevent the assets transfer from principal to the state. However, in taking into consideration of the agency problem in modern company, it is possible that the management will behave as expected in ideal world. Compensation could be the source of the interest conflict between manager and the other stakeholders evoking the earnings management attitude [7]. Since the earnings management misleads the financial report users by bringing the false information about the exact company operational performance, the corporate governance plays a role as the monitor in obstructing the occurrence of earnings management [8]. Therefore, corporate governance is important for the investors to receive information which is not misleading from financial report, as it can repress the company aggressiveness in performing the earnings management. Mansor [9] explains that the corporate governance (CG) mechanism is able to overcome the activities from family-owned companies and the non-familyowned ones. Meanwhile, it is found in researches by Desai [10] ; Hanlon [11]; Lains [12]; Chen [13]; that this mechanism brings negative impact to the tax aggressiveness. In the context of Anglo-Saxon, Ben [14] has studied the correlation between the tax aggressiveness and several 
governance mechanism, and found the contradictive outcome.

In accordance with the previous research gap, therefore the study would aim to develop the research conducted before-about earnings management and tax aggressiveness by adding the corporate governance as the moderating variable. In this research, good corporate governance could be measured with the value of factors analysis result through 4 components of corporate governance mechanism using the Principal Component Analysis (PCA).

\section{LITERATURE REVIEW \& HYPOTHESIS DEVELOPMENT}

\section{A. Agency Theory}

Jensen [15] explains agency theory as the contract between one or several principals delegating the authority to the others (agent) to make decisions in order to perform the company activities. Earning management is one of things that is committed by management as the agent for maximizing the value for the shareholders as the principals.

The company profit would be taxable in term of income. It may cause the occurrence of value transfer from profit section which should probably be received by the shareholders, but moves on government. In this matter, management has to manage the tax expense aggressively to avoid the excessive transfer to government, so that they are persistently able to maximize the value for the shareholders.

However, Jensen [15] states that the company which sets the managing function and ownership one apart would be susceptible toward the agency conflict. Therefore, monitoring the managerial decisions might be important to the board of directors to ensure that the stockholders' interest is protected [16]. The effective monitoring by the board of commissioners and the audit committee would be necessary to confirm the reliable and complete financial reporting. Since the earnings management mislead the financial report users by bringing the false information about the exact company operational performance, the corporate governance play a role as the monitor in obstructing the occurrence of profit management.

\section{B. Goal Setting Theory}

Goal Setting Theory relates to the level of aspiration theory modelling the individual as the willingness of possessing the goal. This theory assumes that a goal chosen individually predisposes their motivation with one out of four mechanisms: goals raise efforts in order to achieve the goal; goals direct the attention and effort; goals increase the persistence; and goals indirectlyaffect the actions by directing to the passion, discovery, and/or the use of science and strategy which are compatible to the task [17].

According to Scott [2], management possesses some motivation to commit the earning management. They purpose to increase or decrease the profit from the previous period of the financial reporting. Meanwhile, Badertscher [18] argue that profit management is employed to manage the income by the non-taxable ways as the effort of tax saving.

\section{Earnings Management}

Scott $\lceil 2\rceil$ defines earning management as "the choice by a manager of accounting policies so as to achieve some specific objectives". Managers use the profit management to expand the reported profit volume [19]. This matter occurs as they are stimulated by several motivations. In accordance with [2] one of these motivation relates to tax. Tax is a primary reason for the company to reduce the reported net profit.

\section{Tax Aggressiveness}

To accord with Frank [4], aggressive tax behavior is the one committed for deducting the taxable profit through the tax planning, using both classified and non-classified tax evasion. Similarly, Chen [13] defines it as a corporate attempt to minimize the tax due by tax planning aggressiveness and tax avoidance. Aggressiveness is a set of behaviors committed by the corporate to reduce the public tax which might be legal or not. To sum up, it is a strategy applied by the managers, process, practice, resource, and options aiming to maximize the earning after submitting the company liabilities to the government and the other stakeholders [20].

In order to minimize the tax expense as the tax aggressiveness goal, a company should repress the fiscal profit value. The value determination might be influenced by the amount of accounting profit resulted by the earning management. Performing profit management for reducing the tax expense becomes the manager tax motivation to perform the earning management. Based on the agency theory, goal setting theory, earning management, and tax aggressiveness explication the study provides, the first hypothesis of this research is:

\section{1) H1: Earning management influences the tax aggressiveness}

\section{a) Corporate Governance}

Agency problem emerges as both of the management and stakeholders probably have different goals. The management is more motivated to short-term goal which is the performance compensation, meanwhile the stockholders depends on the long term one, the company value. Lanis [21] found that tax plays role as the main motivation of the manager's decision. This motivation encourages them to take aggressive tax behaviors to minimize the amount of tax payable affecting the corporate profits both of legally and illegally. The illegal tax aggressiveness may impact the value of the company in the stakeholders' point of views. Thus, this potential interest conflict might be minimized by the corporate governance.

Good Corporate Governance is a company control mechanism in term of fulfilling the external and internal stakeholders' interest. It plays important role in order to monitor the different actor and the scheming of the tax planning procedure [20]. The mechanism could deduct the monitoring cost by increasing the control and monitoring [3].

The monitoring of the managerial decision turns to be significant for the board of directors to guarantee that the 
shareholders interest is protected. Lanis [21] reported that the board of directors numbers has a significant influence on the tax aggressiveness formulation. In contrast, Khaoula [22] argues that there is no relationship between board standard and tax aggressiveness in the American context. They find that the number of directors do not affect the strategy to minimize the tax expense. Minnick [23] suggest that the small board of directors strengthens the good tax management, while it is proven that the large one is seemingly ineffective because of the difficulties in making decisions concerning tax aggressiveness policies.

Since the earnings management misleads the financial report users by bringing the false information about the operational performance, the intern corporate governance board of directors and the audit committee release a regulation concerning the monitoring earnings management activity [8], which is expected to prevent the tax reporting forgery. Dechow [24] discover that the independent directors proportion in the board negatively relates to the fraudulence in financial statement. In addition, Chen [8] also denotes that this board and/or the supervisor ship impact negatively to the profit management. On the other hand, Mansor [9] detects the board independence, audit committee and their measurement, non-multiple directorship, internal audit and company measurement are a set of one of corporate governance mechanism which is able to help to overcome the earnings management problem. Thus, the study formulizes the hypothesis below:

2) H2: Good corporate governance moderates the influence of earnings management toward the tax aggressiveness

\section{RESEARCH METHODOLOGY}

The research is quantitative intending to test the influence of earning management to the tax aggressiveness with corporate governance as the moderating variable. The data employed is the secondary one in the form of annual report and financial statement of companies registered in the Indonesia Stock Exchange (IDX) for 2011-2015 period obtained from the official website of the companies and the IDX website which is www.idx.co.id. The study uses purposive sampling with 756 companies for the samples.

The independent variable is the earning management chosen by the managers as the accounting policy to achieve several specific goals. In this study, the earning management is measured by Discretionary Accrual $\left(D A_{i t}\right)$ calculated by Modified-Jones Model. To reckon $\left(D A_{i t}\right)$, it is required the regression coefficient derived from the regression equation below:

$$
\begin{aligned}
\frac{T_{i t}}{\text { Asset }_{i t-1}}=\alpha_{1}( & \left.\frac{1}{\text { Asset }_{i t-1}}\right)+\alpha_{2}\left(\frac{\Delta R E V_{i t}}{\text { Asset }_{i t-1}}-\frac{\Delta R E C_{i t}}{\text { Asset }_{i t-1}}\right) \\
& +\alpha_{3}\left(\frac{P P E_{i t}}{\text { Asset }_{i t-1}}\right)
\end{aligned}
$$

Where:

$T A_{i t}=\quad$ the icompany total accrual in year $\mathrm{t}$, i.e. the difference of the profit before the unusual post and the discontinued operation with the cash flow within the operation.

$\triangle R E V_{i t} \quad=\quad$ the change of the $\mathrm{i}$ company income in year $\mathrm{t}$ with $\mathrm{t}-1$

$\triangle R E C_{i t} \quad=\quad$ the change of account receivable of company $i$ in year $t$ and $t-1$

$P P E_{\text {it }} \quad=$ gross fixed asset value of company $\mathrm{i}$ in year $\mathrm{t}$

Afterwards, to calculate the Normal Discretionary Accrual $\left(N D A_{i t}\right)$, the regression coefficient value is included into following formula:

$$
\begin{gathered}
N D A_{i t}=\alpha_{1}\left(\frac{1}{\text { Asset }_{i t-1}}\right)+\alpha_{2}\left(\frac{\Delta R E V_{i t}}{\text { Asset }_{i t-1}}-\frac{\Delta R E C_{i t}}{\text { Asset }_{i t-1}}\right) \\
+\alpha_{3}\left(\frac{P P E_{i t}}{\text { Asset }_{i t-1}}\right)
\end{gathered}
$$

Subsequently, the Normal Discretionary Accrual $\left(N D A_{i t}\right)$ is applied to reckon the Discretionary Accrual $\left(D A_{i t}\right)$ by using the formula below:

$$
D A_{i t}=\frac{T A_{i t}}{\text { Asset }_{i t-1}}-N D A_{i t}
$$

The dependent variable of the study is the tax aggressiveness which aims to minimize the tax due through the tax planning aggressiveness and tax avoidance. In this case, tax aggressiveness would be measured by Book Tax Difference (BTD) - a difference between the company profit before the tax reduced and the fiscal profit (taxable one). Book Tax Difference (BTD) reflects the tax aggressiveness behavior committed by the company in reporting the financial statement and it differs the reporting based on the accounting standard and the one intending to determine the tax expense. Here is the formula:

$$
B T D_{i t}=\frac{\text { PretaxAccountingIncome }_{i t}-\text { Fiscal Profit }_{i t}}{\text { Total Asset }_{i t-1}}
$$

Corporate Governance $\left(\mathrm{CG}_{i t}\right)$ is the other dependent variable functioning as the moderator. It is a company control mechanism in order to run effectively in fulfilling the external and internal stakeholders' interest. It is with the value of the factor analyzing result of 4 (four) components of corporate governance mechanism using the Principal Component Analysis (PCA). Those four components are: 


\section{a) Institutional Ownership}

Institutional Ownership (IO) is measured based on the share percentage possessed by the institution divided with the amount of distributed share. It could be explained through the following formula:

$$
I O_{i t}=\frac{\text { Amount of the Shares Possessed by the institution }}{\text { it }} \times 100 \%
$$

\section{b) Independent Board of Directors}

The Independent Board of Directors (IBD) is measured in accordance with the numbers of independent directors with the whole members of the board of directors within a company. It can be calculated by using the formula below:

$$
I B D_{i t}=\frac{\text { The Number of the Independent Board of Directors }}{i t}=100 \%
$$

\section{c) Board of Directors}

Board of Directors (BD) is measured in accord with their number in a company, which can be depicted through the following formula:

$$
B D_{i t}=\text { Amount of the Board of Directors }{ }_{i t}
$$

\section{d) Audit Committee}

The Audit Committee (AC) could be measured through each of companies employed as the sample which is formulized below:

$$
A C_{i t}=\text { The Amount of the Audit Committee } \text { Cit }_{1}
$$

The study chooses the regression test with significance level $5 \%$ for the analysis technique.

\section{FINDINGS AND DiscUSSION}

\section{A. Earnings Management Influence toward Tax}

\begin{tabular}{|c|c|c|c|c|c|}
\hline \multirow[b]{2}{*}{ Model } & \multicolumn{2}{|c|}{$\begin{array}{c}\text { Unstandardized } \\
\text { Coefficients }\end{array}$} & \multirow{2}{*}{\begin{tabular}{|c|}
$\begin{array}{c}\text { Standardiz } \\
\text { ed } \\
\text { Coefficient } \\
\text { s }\end{array}$ \\
Beta \\
\end{tabular}} & \multirow[b]{2}{*}{$\mathbf{T}$} & \multirow[b]{2}{*}{ Sig. } \\
\hline & $B$ & Std. Error & & & \\
\hline (Constant) & -3.164 & .116 & & -27.204 & .000 \\
\hline LN_DA & .301 & .075 & .202 & 4.007 & .000 \\
\hline
\end{tabular}
Aggressiveness

TABLE 4.1 Hypothesis TEST RESUlT

COEFFICIENTS $^{\mathrm{A}}$

In accordance with the result of statistic test on table 4.1, it is denoted that the significance value is about 0.000 , meaning the first hypothesis of earning management influences the tax aggressiveness can be accepted. The more aggressive the company perform the earnings management the higher the effort of committing the tax aggressiveness would be.
The result above confirms that one of manager goals in executing the earnings management is tax motive [2]. In order to minimize the amount of tax due, it is attempted to harmonize the effort of tax aggressiveness and earnings management with the management of commercial and fiscal profit.

It supports the research belonging to Frank [25] that there is a positive correlation of tax aggressiveness and aggressive tax reporting. Also, it is aligned to Dwi [26] research, that the profit management in the form of income decreasing impacts to the tax aggressiveness because the profit is the standard to measure the amount of company tax expense. Therefore, the management would report the profit which is compatible to the intention to take accounting option which is income decreasing as the form of tax avoidance. The more corporate applies income decreasing, the lesser the tax that should be paid. Thus, the more aggressive the effort in performing the decreasing, the more aggressive the company would be in terms of taxation. However, this study rejects Heltzer [5] research result, investigating the financial tradeoff encountered by the manager to report the higher commercial income and, at the same time, to report the lower taxable income.

\section{B. The Earning Management Influence toward Tax Aggressiveness with Corporate Governance is the

\begin{tabular}{|c|c|c|c|c|c|}
\hline \multirow[b]{2}{*}{ Model } & \multicolumn{2}{|c|}{$\begin{array}{c}\text { Unstandardized } \\
\text { Coefficients }\end{array}$} & \multirow{2}{*}{\begin{tabular}{|c|}
$\begin{array}{c}\text { Standardi } \\
\text { zed } \\
\text { Coefficien } \\
\text { ts }\end{array}$ \\
Beta \\
\end{tabular}} & \multirow[b]{2}{*}{$T$} & \multirow[b]{2}{*}{ Sig. } \\
\hline & $B$ & Std. Error & & & \\
\hline (Constant) & -2.482 & .200 & & 12.429 & .000 \\
\hline LN_DA & .608 & .123 & .431 & 4.947 & .000 \\
\hline LN_CG & .354 & .126 & .321 & 2.798 & .006 \\
\hline $\begin{array}{c}\text { LN_CG_LN } \\
\text { DA }\end{array}$ & 179 & .088 & .247 & 2.031 & .044 \\
\hline
\end{tabular} moderating variable.}

TABLE 4.2 Hypothesis Test Result

COEFFICIENTS $^{\wedge}$

According to the statistic test result on table 4.2, it reflects that the CG significance value to BTD is about 0.006 and the significance value of the interaction between $\mathrm{CG}$ and DA is 0.044. Referring to Ghozali [27], if the interaction of moderator variable and both of independent and dependent variable are significant, it would be assessed as quasi moderation. Thus, in this case, Corporate Governance is a variable moderating the relationship of earnings management and tax aggressiveness which plays a role as the independent variable. Therefore, in accordance with the test result, the second hypothesis could be accepted.

As the earnings management biases the users of financial statements by providing incorrect information about the operation performance, the corporate governance board of directors and audit committee applying the regulation in 
monitoring the earnings management activity [8] which is also expected to prevent tax reporting forgery.

The results of this study develop [3] research stating that the corporate governance possesses the significant effect on the earnings and tax management. The results reflect that the corporate governance as an independent variable affecting to the tax aggressiveness, is also a moderating variable for the earnings management on tax aggressiveness. Moreover, the results support Kasipillai [28] research concerning that public company adopts earnings management to avoid deducting revenue by manipulating earnings before tax with accruals of income and expenses, and also by employing the component of valuation adjustment of deferred tax liabilities. The components of deferred tax liabilities for earnings management activities more likely occur when the principles of good corporate governance are not applied.

In pursuance of agency theory, the corporate governance takes negative effect toward the tax aggressiveness. The better its mechanism is the lower the tax aggressiveness would be. In fact, the result of the study brings the positive relation, meaning that the higher the corporate governance is, the higher the aggressiveness becomes. The dissimilarity here is emerged because of the adopting of corporate governance measured by the value from the factors analysis result of 4 (four) components of its mechanism combining the Principal Component Analysis (PCA). The higher several components turn to be, the stronger the tax aggressiveness would become, such as the number of the board of directors. In this case, the greater the number of them, surprisingly the looser the monitoring system would be.

Agency problems arise as the management has a different purpose with the shareholders. The management possesses motivation towards short-term goals of performance compensation, meanwhile the shareholders are more motivated towards the long-term goal of the corporate value. Through the short-term goal motivation, it encourages aggressive tax behavior to minimize the amount of tax payable that affects both legally and illegally corporate profits. For the shareholders, the illegallytax aggressiveness can have an impact on the value of the company. This potential conflicts of interest might be minimized by good corporate governance.

The results of this study is relevant with research from Lanis [21], that the measurement of the board significantly influences the formulation of the tax aggressiveness. Chi [29] argue that the corporate governance affects the tax aggressiveness denoted by the number of shares owned by the directors, the board independence and shareholder significantly take an effect to the effective tax rate (corporate tax aggressiveness). In addition, Boussaidi [20] highlights the role of diversification of the board of directors and managerial ownership for the tax aggressiveness deduction.

\section{CONClusion \& Suggestion}

Through the hypothesis test result, it could be concluded that: 1) earnings management influences the tax aggressiveness; 2) Corporate governance is a quasi moderation meaning which is able to moderate the relation between the earning management and tax aggressiveness, the independent variable.

The effort for the earning management for tax reporting forgery can minimize the application of the corporate governance. In accordance with those proofs, the researchers suggest to all companies and government to be serious in concerning the corporate governance as the way to reduce the tax aggressiveness practice.

\section{REFERENCES}

[1] C. Rica, "OECD Progress Report A Progress Report On The Jurisdictions Surveyed By The OECD Global Forum In Implementing The Internationally Agreed Tax Standard," vol. 2012, no. April 2009, p. 2012, 2012.

[2] S. W, R, Financial Accounting Theory. University of Waterloo Prentice Hall Canada Inc, 2003.

[3] M. S. Mulyadi and Y. Anwar, "Corporate Governance, Earnings Management and Tax Management," Procedia - Soc. Behav. Sci., vol. 177, no. July 2014, pp. 363-366, 2015.

[4] M. M. Frank, L. J. Lynch, and S. O. Rego, "Tax Reporting Aggressiveness to Aggressive and Its Relation Financial Reporting," Account. Rev., vol. 84, no. 2, pp. 467-496, 2009.

[5] W. Heltzer, M. P. Mindak, and S. W. Shelton, "Research in Accounting Regulation The relation between aggressive financial reporting and aggressive tax reporting: Evidence from ex-Arthur Andersen clients," Res. Account. Regul., vol. 24, no. 2, pp. 96-104, 2012.

[6] B. Badertscher and S. P. Katz, "The Impact of Private Equity Ownership on Corporate Tax Avoidance," no. 319, 2009.

[7] C. Lennox, X. Wu, and T. Zhang, "The effect of audit adjustments on earnings quality: Evidence from China," J. Account. Econ., vol. 61, no. 2-3, pp. 545-562, 2016.

[8] K. Y. Chen, R. J. Elder, and Y. Hsieh, "Corporate Governance and Earnings Management: The Implications of Corporate Governance Best-Practice Principles for Taiwanese Listed Companies," vol. 3, no. 2, pp. 73-105, 2007.

[9] N. Mansor, A. Che-Ahmad, N. A. Ahmad-Zaluki, and A. H. Osman, "Corporate Governance and Earnings Management: A Study on the Malaysian Family and Non-family Owned PLCs," Procedia Econ. Financ, vol. 7, no. Icebr, pp. 221-229, 2013.

[10] M. a. Desai and D. Dharmapala, "Corporate Tax Avoidance and High Powered Incentives,” J. financ. econ., no. April, p. 42, 2004.

[11] M. Hanlon and J. Slemrod, "What does tax aggressiveness signal? Evidence from stock price reactions to news about tax shelter involvement 2009.

[12] R. Lanis and G. Richardson, "The effect of board of director composition on corporate tax aggressiveness," J. Account. Public Policy, vol. 30, no. 1, pp. 50-70, 2011.

[13] S. Chen, X. Chen, and T. Shevlin, "Are Family Firms more Tax Aggressive than Non- family Firms?," J. financ. econ., vol. 95, no. 1, pp. 41-61, 2010.

[14] A. Ben Amar and E. Abaoub, "Earnings Management Thresholds: the Case in Tunisia," vol. 6, no. 2, pp. 35-56, 2010.

[15] C. Jensen and H. Meckling, "Theory Of The Firm: Managerial Behaviour, Agency Costs and Ownership Structure," J. financ. econ., vol. 3, pp. 305-360, 1976.

[16] E. F. Fama, M. C. Jensen, S. Journal, and P. P. A, "Separation of Ownership and Control Separation of Ownership and Control *," vol. 26, no. 2, pp. 301-325, 2009.

[17] J. G. Birnberg, J. Luft, and M. D. Shields, "Psychology Theory in Management Accounting Research," Handbooks Manag. Account. Res., vol. 1, no. January, pp. 113-135, 2006.

[18] B. A. Badertscher, John D. Phillips, Morton Pincus, and Sonja Olhoft Rego, "Earnings Management Strategies and the Trade-Off 
between Tax Benefits and Detection Risk: To Conform or Not to Conform?," Account. Rev., vol. 84, 2009.

[19] N. U. Miko and H. Kamardin, "Impact of Audit Committee and Audit Quality on Preventing Earnings Management in the Pre- and Post- Nigerian Corporate Governance Code 2011," Procedia - Soc. Behav. Sci., vol. 172, pp. 651-657, 2015.

[20] A. Boussaidi, "THE IMPACT OF GOVERNANCE MECHANISMS ON TAX AGGRESSIVENESS : EMPIRICAL EVIDENCE FROM TUNISIAN CONTEXT 2 . TAX AGGRESSIVENESS : LIGHTING AND DISTINCTION," vol. 5, no. 1, pp. 1-12, 2015.

[21] R. Lanis, G. Richardson, R. Lanis, and G. Richardson, "Corporate social responsibility and tax aggressiveness: a test of legitimacy theory," 2012.

[22] A. Khaoula and Z. Mohamed Ali, "Demographic Diversity in the Board and Corporate Tax Planning in American Firms," Bus. Manag. Strateg., vol. 3, no. 1, pp. 72-86, 2012.

[23] K. Minnick and T. Noga, "Do corporate governance characteristics in fl uence tax management?," vol. 16, pp. 703-718, 2010.
[24] P. Dechow, A. Hutton, J. H. Kim, and R. G. Sloan, "Detecting earnings management: A new approach," J. Account. ..., vol. 50, no. April 2011, pp. 275-334, 2012.

[25] M. M. Frank, "Tax Reporting Aggressiveness and Its Relation to Aggressive Financial Reporting Mary," 2008.

[26] S. K. Dwi and Supramono, "Likuiditas, leverage , komisaris independen, dan manajemen laba terhadap agresivitas pajak perusahaan," vol. 16, no. 2, 2012.

[27] I. Ghozali, Aplikasi Analisis Multivariete Dengan Program IBM SPSS 23, 8th ed. Semarang: Badan Penerbit Universitas Diponegoro, 2016.

[28] J. Kasipillai and S. Mahenthiran, "Deferred taxes, earnings management, and corporate governance: Malaysian evidence," $J$. Contemp. Account. Econ., vol. 9, no. 1, pp. 1-18, 2013.

[29] Y. Chi and K. Timothy, "Effects of corporate governance on tax aggressiveness BY," no. April, 2010. 